\title{
Formulation and Permeation Kinetic Studies of Flurbiprofen Gel
}

\author{
Rao Khurram Ayoub ${ }^{1}$, Ghulam Murtaza ${ }^{2 *}$, Muhammad Imran ${ }^{1}$, Shujaat Ali \\ $\mathrm{Khan}^{2}$, Sadullah Mir ${ }^{3}$, Abida Kalsoom Khan ${ }^{3}$, Saira Azhar ${ }^{2}$, Zahid Mehmood ${ }^{3}$, \\ Ashif Sajjad ${ }^{3}$ and Syed Nisar Hussain Shah ${ }^{1}$ \\ ${ }^{1}$ Faculty of Pharmacy, Bahauddin Zakariya University, Multan, ${ }^{2}$ Department of Pharmacy, COMSATS Institute of Information \\ Technology, Abbottabad, ${ }^{3}$ Institute of Biochemistry, University of Balochistan, Quetta, Pakistan
}

*For correspondence: Email: gmdogar356@gmail.com; Tel: 00923142082826; Fax: 0092992383441

\begin{abstract}
Purpose: To investigate the in vitro permeation and drug release kinetics of flurbiprofen gel.

Methods: Thirteen batches $\left(G_{1}, G_{2} \ldots G_{13}\right)$ of flurbiprofen gels were prepared using different ratios of permeation enhancers, i.e., propylene glycol (PG) and polyethylene glycol (PEG), by response surface methodology (RSM). Viscosity, $\mathrm{pH}$, spreadability, consistency and drug content of the flurbiprofen gels were measured. Permeation experiments were conducted using silicone membrane in a modified Franz diffusion cell. Permeation parameters determined include diffusion coefficient $(D)$. Flux (J), lag time (tLag), permeation coefficient (Kp), input rate (IR) and enhancement ratio (ER). Primary skin irritation test was performed for the optimized gel, $G_{3}$, using 11 human volunteers.

Results: Maximum solubility $(72.15 \pm 0.02 \mathrm{mg} / \mathrm{mL})$ of flurbiprofen was observed in a mixture (2:1) of methanol and water. Partition coefficient $\left(K_{0} / w\right)$ was determined as $\log P=3.68 \pm 0.11$. The gels were stable under various storage conditions, and were homogenous, crystalline and transparent. Viscosity, $\mathrm{pH}$, spreadability, consistency and drug content were in the range of $150-178 \times 10^{2} \mathrm{cps}, 5.42-5.75$, $5.0-7.0 \mathrm{~g} . \mathrm{cm} / \mathrm{s}, 3.0-9.0 \mathrm{~mm}$, and $97.99-99.86 \%$, respectively. No irritation or lesions (erythma, redness and ulceration) occurred in human volunteers over a 30-day period. The optimized formulation, G3, showed maximum flux through silicone membrane.

Conclusion: PG and PEG are effective enhancers of flurbiprofen from various formulations when used in various ratios.
\end{abstract}

Keywords: Flurbiprofen, Gel, Diffusion, Permeation enhancers, Skin irritation, Silicone membrane

Tropical Journal of Pharmaceutical Research is indexed by Science Citation Index (SciSearch), Scopus, International Pharmaceutical Abstract, Chemical Abstracts, Embase, Index Copernicus, EBSCO, African Index Medicus, JournalSeek, Journal Citation Reports/Science Edition, Directory of Open Access Journals (DOAJ), African Journal Online, Bioline International, Open-J-Gate and Pharmacy Abstracts

\section{INTRODUCTION}

The physicochemical, pharmacokinetic, and pharmacodynamic properties of flurbiprofen make it a worthy candidate for transdermal drug delivery [1,2]. It has a molecular weight of 244.26 Daltons and value of $\log \mathrm{P}$ (octanol/water, $\mathrm{pH}$ 7.4 ) is 3.80 . It is mainly metabolized in the liver, which attracts its suitability for percutaneous delivery [3-5].
Extensive research studies are being carried out to explore various approaches for promoting drug delivery across skin. Some of these approaches involve the incorporation of drug into microcapsules, nanocapsules, niosomes, liposomes, emulsion-based systems, and use of different vehicle-chemical enhancer combinations (6-8). Chemical enhancers are substances which temporarily reduce skin barrier features 
leading to increased drug absorption [6]. Some examples of these enhancers are essential oils, terpenes, and fatty acids. Many in vitro studies have suggested that propylene glycol (PG) and polyethylene glycol (PEG) are capable of easily penetrating across the skin elaborating their role as skin penetration enhancers [9-11].

The objective of this study was to investigate the permeation and drug release kinetics flurbiprofen gels using silicone membrane in modified Franz diffusion cells with the aid of surface response methodology.

\section{EXPERIMENTAL}

\section{Materials}

Flurbiprofen (99.9 \% purity) was purchased from Merck, Germany. All other chemicals including carbopol 934, benzyl alcohol, propylene glycol (PG), polyethylene glycol (PEG 1000), triethanolamine, ethylene glycol, peppermint oil, and methanol, used were of analytical grade and were also purchased from Merck, Germany through a local source, Adamjee and Sons, Rawalpindi, Pakistan.

\section{Preparation of hydro-alcohol flurbiprofen gels}

Dilution solution was prepared by mixing methanol and water in ratio of $2: 1$. Hydroalcoholic gels (20 g of each formulation) of flurbiprofen having various concentrations of permeation enhancers i.e. PG and PEG were prepared as per the composition in Table 1.

Table 1: Composition of gels (20 g)

\begin{tabular}{lc}
\hline Ingredients & Amount (g) \\
\hline Flurbiprofen & 0.4 \\
Carbopol 934 & 0.5 \\
Benzyl Alcohol & 1.6 \\
PG & $2-6$ \\
PEG-1000 & $0.5-2.5$ \\
Triethanolamine & 0.9 \\
Ethylene glycol & 0.1 \\
Peppermint Oil & 0.4 \\
Methanol & 6.3 \\
Distilled Water & q.s. to $20 \mathrm{~g}$ \\
\hline
\end{tabular}

In the preparation of flubiprofen gels, $10 \mathrm{~mL}$ of diluting solution was taken in conical flask, then $400 \mathrm{mg}$ flurbiprofen was dissolved in it and PEG was added with continuous stirring using a magnetic stirrer till complete dissolution. PG was taken in another conical flask, and then $500 \mathrm{mg}$ carbopol-934 was added into it. Magnetic stirring was continued till carbopol dissolved, and then triethanolamine was added to neutralize carbopol-934. Then drug solution (first solution) was added to second solution containing homogenized preparation of carbapol 934, PG and triethanolamine under continuous magnetic stirring followed by the addition of benzyl alcohol and ethylene glycol. Finally, peppermint oil was added for fragrance and the formulations were stored in collapsible tubes for further use. The formulation design is given in Table 2 .

Table 2: Composition of gels $\left(\mathrm{G}_{1} \ldots . . \mathrm{G}_{13}\right)$

\begin{tabular}{|c|c|c|c|c|c|c|c|c|c|c|}
\hline 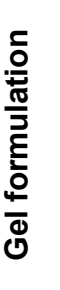 & 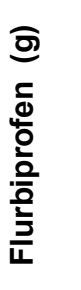 & 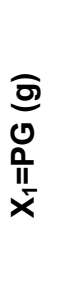 & 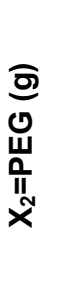 & 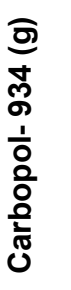 & 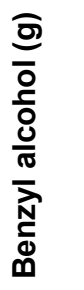 & 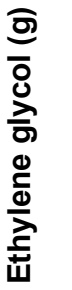 & 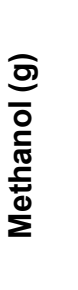 & 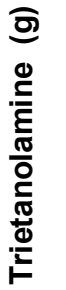 & 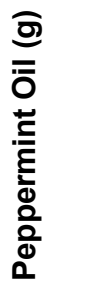 & 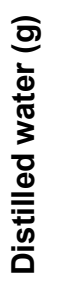 \\
\hline $\mathrm{Gc}$ & 0.4 & 0 & 0 & 0.5 & 1.6 & 0.1 & 6.3 & 0.9 & 0.3 & 9.9 \\
\hline $\mathrm{G}_{1}$ & 0.4 & 3.0 & 1.0 & 0.5 & 1.6 & 0.1 & 6.3 & 0.9 & 0.3 & 5.9 \\
\hline $\mathrm{G}_{2}$ & 0.4 & 5.0 & 1.0 & 0.5 & 1.6 & 0.1 & 6.3 & 0.9 & 0.3 & 3.9 \\
\hline $\mathrm{G}_{3}$ & 0.4 & 3.0 & 2.0 & 0.5 & 1.6 & 0.1 & 6.3 & 0.9 & 0.3 & 4.9 \\
\hline $\mathrm{G}_{4}$ & 0.4 & 5.0 & 4.8 & 0.5 & 1.6 & 0.1 & 6.3 & 0.9 & 0.3 & 0.1 \\
\hline $\mathrm{G}_{5}$ & 0.4 & 2.0 & 1.5 & 0.5 & 1.6 & 0.1 & 6.3 & 0.9 & 0.3 & 6.4 \\
\hline $\mathrm{G}_{6}$ & 0.4 & 6.0 & 1.5 & 0.5 & 1.6 & 0.1 & 6.3 & 0.9 & 0.3 & 2.4 \\
\hline $\mathrm{G}_{7}$ & 0.4 & 4.0 & 0.5 & 0.5 & 1.6 & 0.1 & 6.3 & 0.9 & 0.3 & 5.4 \\
\hline $\mathrm{G}_{8}$ & 0.4 & 4.0 & 2.5 & 0.5 & 1.6 & 0.1 & 6.3 & 0.9 & 0.3 & 3.4 \\
\hline $\mathrm{G}_{9}$ & 0.4 & 4.0 & 1.5 & 0.5 & 1.6 & 0.1 & 6.3 & 0.9 & 0.3 & 4.4 \\
\hline $\mathrm{G}_{10}$ & 0.4 & 4.0 & 1.5 & 0.5 & 1.6 & 0.1 & 6.3 & 0.9 & 0.3 & 4.4 \\
\hline $\mathrm{G}_{11}$ & 0.4 & 4.0 & 1.5 & 0.5 & 1.6 & 0.1 & 6.3 & 0.9 & 0.3 & 4.4 \\
\hline $\mathrm{G}_{12}$ & 0.4 & 4.0 & 1.5 & 0.5 & 1.6 & 0.1 & 6.3 & 0.9 & 0.3 & 4.4 \\
\hline $\mathrm{G}_{13}$ & 0.4 & 4.0 & 1.5 & 0.5 & 1.6 & 0.1 & 6.3 & 0.9 & 0.3 & 4.4 \\
\hline
\end{tabular}




\section{Flurbiprofen assay}

The calibration curve for flurbiprofen was also constructed in a concentration range of $10-100$ $\mu \mathrm{g} / \mathrm{ml}$. The regression equation for calibration curve was $Y=0.0058 x+0.3133$ with regression coefficient $\left(R^{2}\right)=0.9979$, where $Y=$ absorbance at $247 \mathrm{~nm}, \mathrm{a}=$ slope, $\quad \mathrm{b}=$ intercept, and $\mathrm{X}=$ concentration $(\mu \mathrm{g} / \mathrm{mL})$ of flurbiprofen.

\section{In vitro diffusion studies through silicon membrane}

Franz-type diffusion cells were used for the diffusion studies across silicone membrane with a diffusional area of $\sim 0.788 \mathrm{~cm}^{2}$ and receptor phase volume of $\sim 5 \mathrm{~mL}$ [9]. Silicone membrane was cut to appropriate sizes in round-shape and soaked overnight in the receptor solution [mixture of methanol and water; $(2: 1 \mathrm{v} / \mathrm{v})]$. The membrane was then placed in between the two compartments, donor and receptor, of the diffusion cells. Before placing the membrane, vacuum grease (Noravan Diagnostics, Belgium) was applied on the inner surfaces (collar) of the two compartments to produce a leak-proof seal system. Furthermore, the two compartments were clamped after placing donor over receptor compartment. Receptor fluid was filled in the receptor compartment through cell arm and was degassed in an ultrasonic bath to remove air bubbles and prevent the build-up of air pockets in the receptor phase. For uniform mixing of the receptor phase, magnetic stirring bar was placed in the receptor compartment. Then opening of cell arm of receptor and circumference of the donor was covered with a parafilm to prevent evaporation. The diffusion cells were placed on a stirring bed immersed in a water bath at $37 \pm 1$ ${ }^{\circ} \mathrm{C}$ to maintain a temperature at the membrane surface. After $1 \mathrm{~h}$, the receptor phase was completely removed and refilled with pre-thermo stated receptor fluid. The donor compartment was charged with $1 \mathrm{~mL}$ of the test solution (flurbiprofen gel). $0.2 \mathrm{~mL}$ of sample from receptor solution was drawn using micropipette at definite time intervals of $15,30,45,60,90,120$ and 180 min. After each withdrawal of sample, $0.2 \mathrm{ml}$ of pre-thermostated receptor fluid was added to receptor compartment to maintain sink condition. The samples were analyzed spectrophotometrically at $247 \mathrm{~nm}$ [1] to obtain the amount permeated through silicon membrane. Experiments were conducted in triplicate.

\section{In vitro diffusion studies through rat skin}

Diffusion studies of the flurbiprofen gels across rat skin were carried out using two chambered modified Franz-type diffusion cells having a receptor phase of $\sim 5 \mathrm{~mL}$, and a diffusional area of $\sim 0.788 \mathrm{~cm}^{2}$.

Following approval (ref no. 86-2010/BZU.PHM) by the Board of Advance Studies and Research, Faculty of Pharmacy, Bahauddin Zakariya University, Multan, Pakistan, this study was carried out according to international guidelines for animal use in laboratory experiments [9]. Abdominal skin of rat was carefully excised after sacrificing the rat. Subcutaneous fats and other extraneous tissues adhering to the dermis were completely removed and trimmed off with forceps and scissor. The skin was cleaned with PBS $(\mathrm{pH}$ 7.4) and stored in $500 \mathrm{ml}$ normal saline in refrigerator $\left(-20^{\circ} \mathrm{C}\right)$, the skin was then used within one week [9]. Sheets of rat skin were cut to appropriate sizes $\left(\sim 1 \mathrm{~cm}^{2}\right)$ in round-shape.

The membrane was then placed between the two compartments of the diffusion cells with epidermis side facing the donor compartment while the dermal side bathed with the receptor fluid. Then same methodology was adopted as narrated in above section, i.e. in vitro diffusion studies through silicon membrane. Then, factor of difference (FoD) of permeation studies of flurbiprofen gel across rat skin vs. silicone membrane was determined.

\section{Application of response surface methodology (RSM)}

Stat-Ease design Expert $\circledast$, version 7.0.3, was used to produce and assess the statistical experimental design and construct a design matrix. This computer optimization technique (Table 3) based on response surface methodology (RSM) utilizing polynomial equation was used to determine the optimal gel formulation and quantify the influences of formulation variables on the drug permeation. A central composite design (CCD) considering $\alpha$ equal to two was employed as per standard protocol. The amount of PG and PEG was selected as the factors, studied at five levels each. The central point $(0,0)$ was studied in quintuplicate. All other formulation and process variables were kept invariant throughout the study.

\section{Solubility studies}

Pure flurbiprofen in excess amount was added in separate glass bottles containing $5 \mathrm{~mL}$ of two solvents i.e. methanol and distilled water. These mixtures were stirred in a thermostatically controlled stirrer at a constant temperature of 37 ${ }^{\circ} \mathrm{C} \pm 1$ for $48 \mathrm{~h}$. The mixtures were then centrifuged at $13,000 \mathrm{rpm}$ for $15 \mathrm{~min}$ and 
supernatant aliquot was taken out by a pipette and analyzed using UV-spectrophotometer at $247 \mathrm{~nm}$ to determine the concentration in $\mu \mathrm{g} / \mathrm{mL}$.

\section{Evaluation of partition coefficient}

A small amount of flurbiprofen was dissolved in $0.1 \mathrm{~N}$ methanolic sodium hydroxide and mixed with equal amount of octanol in a separating funnel. The mixture was shaken vigorously for 10 $\min$ and left to stand for about $12 \mathrm{~h}$. The separated layers were collected in test tubes and analyzed using UV spectrophotometer at $247 \mathrm{~nm}$ and then the octanol/water ratio was computed. Each experiment was carried out in triplicate.

\section{Assessment of physical properties}

The appearance and other physical properties, including clarity and precipitation of the prepared gels were inspected. Viscosity was determined by using Brookfield viscometer (Model RVTDV II, Brookfield Engineering Laboratories, Inc, Stoughton, MA). Viscosity measurements were carried out at room temperature $\left(25-27^{\circ} \mathrm{C}\right)$. The $\mathrm{pH}$ of the prepared lotions was measured at $25 \pm 0.5^{\circ} \mathrm{C}$ using Digital $\mathrm{pH}$ meter (WTW, pH 526 Germany).

Spreadability was estimated by wooden block and glass slide apparatus [9]. Flubiprofen gel weighing about $20 \mathrm{~g}$ were added to the sterile pan and the time for upper slide (movable) to separate completely from the fixed slide was accurately noted. Spreadability was calculated as in Eq 1.
$S=M \cdot L / T$

where $\mathrm{S}=$ spreadability, $\mathrm{M}=$ weight moved to upper slide, $\mathrm{L}=$ length of glass slide, and $\mathrm{T}=$ time taken to separate the slide completely from each other.

The evaluation of consistency of the gels was done by dropping a cone attached to a holding rod from a fixed distance of $10 \mathrm{~cm}$ in other way that it should fall down on the centre of the glass cup was filled with the gel. The penetration by the cone was accurately measured from the surface of the gel to the tip of the cone inside of the gel. The distance traveled by cone in the period was noted down after $10 \mathrm{~s}$.

A proforma containing six questions was prepared and given to each volunteer (total of eleven volunteers) for sensory evaluation of the optimized gel $\mathrm{G}_{4}$ and average points were calculated from the responses (scoring was from -4 to +4 indicating very bad to excellent respectively) by each volunteer for each question.

\section{Determination of drug content}

A specified quantity (100 mg) of gel was dissolved in $100 \mathrm{~mL}$ of phosphate buffer of $\mathrm{pH}$ 6.8. The volumetric flask containing gel solution was shaken for the period $2 \mathrm{~h}$ on mechanical shaker in order to get absolute solubility of drug. This solution was filtered and estimated spectrophotometrically at $247 \mathrm{~nm}$ using phosphate buffer ( $\mathrm{pH}$ 6.8) as blank.

Table 3: Factor combinations as per (a) chosen experimental design and (b) translation of coded levels in actual units

(a)

\begin{tabular}{lcccc}
\cline { 1 - 3 } Trial no. & \multicolumn{2}{c}{ Coded Factor levels } & PG $\mathbf{~ ( g ) ~}$ & PEG (g) \\
\cline { 2 - 3 } & $\mathbf{X}_{\mathbf{1}}$ (PG) & $\mathbf{X}_{\mathbf{2} \text { (PEG) }}$ & & \\
\hline I & -1 & -1 & 3.0 & 1.0 \\
II & 1 & -1 & 5.0 & 1.0 \\
III & -1 & 1 & 3.0 & 2.0 \\
IV & 1 & 1 & 5.0 & 2.0 \\
V & -2 & 0 & 2.0 & 1.5 \\
VI & 2 & 0 & 6.0 & 1.5 \\
VII & 0 & -2 & 4.0 & 0.5 \\
VIII & 0 & 2 & 4.0 & 2.5 \\
IX & 0 & 0 & 4.0 & 1.5 \\
X & 0 & 0 & 4.0 & 1.5 \\
XI & 0 & 0 & 4.0 & 1.5 \\
XII & 0 & 0 & 4.0 & 1.5 \\
XIII & 0 & 0 & 4.0 & 1.5 \\
\hline
\end{tabular}

(b)

\begin{tabular}{lccccc} 
(b) & $\mathbf{- 2}$ & $\mathbf{- 1}$ & $\mathbf{0}$ & $\mathbf{1}$ & $\mathbf{2}$ \\
\hline Coded levels & 2 & 3 & 4 & 5 & 6 \\
X 1 (PG)g & 0.5 & 1.0 & 1.5 & 2.0 & 2.5 \\
X 2 (PEG) g & &
\end{tabular}




\section{Primary skin irritation test}

Primary test for irritation (Draize's skin irritation test) [10] was performed on human volunteers [9]. For the optimized gel $\mathrm{G}_{3}$, eleven volunteers were selected and small amount of formulated gel was applied on an area of 2 square inch to the back of hand. The volunteers were observed for lesions or irritation.

\section{Stability studies}

Stability studies were performed on the optimized gel G3. The formulations were packed in collapsible aluminum tubes $(5 \mathrm{~g})$ and subjected to stability studies at $25{ }^{\circ} \mathrm{C} / 60 \% \mathrm{RH}$ and 40 ${ }^{\circ} \mathrm{C} / 75 \% \mathrm{RH}$ for a period of three months. Samples were withdrawn after specified time and evaluated for physical appearance, rheological properties and chemical assay.

\section{Statistical analysis}

Microsoft Excel, version 2007, was used to carry out statistical data analysis including calculation of mean and standard deviation. Statistically significant differences, among various parameters of 13 different formulations, were determined using the regression analysis and analysis of variance (ANOVA) with $p<0.05$ as a minimal level of significance.

\section{RESULTS}

\section{Solubility of flurbiprofen}

The solubility of flurbiprofen in water was $0.01 \pm$ $0.01 \mathrm{mg} / \mathrm{mL}$, in methanol $69.20 \pm 0.01 \mathrm{mg} / \mathrm{mL}$, in normal saline $0.27 \pm 0.01 \mathrm{mg} / \mathrm{mL}$, in PBS $17.62 \pm$ $0.03 \mathrm{mg} / \mathrm{ml}$, in PBS mixed with methanol $61.71 \pm$ $0.15 \mathrm{mg} / \mathrm{ml}$ while in mixture of methanol and water (2:1), solubility was $72.15 \pm 0.02 \mathrm{mg} / \mathrm{ml}$.

\section{Partition coefficient}

Partition coefficient $\left(\mathrm{K}_{\mathrm{o} / \mathrm{w}}\right)$, expressed as $\log \mathrm{P}$, was $3.68 \pm 0.11$, compared with a previously reported value of $\log P=3.80$ [20].

\section{Physical properties}

The appearance and other physical properties including clarity, precipitation and homogeneity of the prepared gels were observed and all the prepared gels were found homogenous, white crystalline and transparent. Viscosity, $\mathrm{pH}$, spreadability, consistency and drug contents values of the flurbiprofen gels were measured and found as shown in Table 5.

\section{Skin irritation}

Primary skin irritation test was performed for optimized gel $\mathrm{G}_{3}$ on 11 volunteers and found no irritation or lesions (erythma, redness and ulceration) over a 30-day.

\section{Stability of gel}

For stability testing, the optimized flurbiprofen gel $\mathrm{G}_{3}$ was stored for three months as per $\mathrm{ICH}$ norms at $25 \pm 1{ }^{\circ} \mathrm{C}, 60 \% \mathrm{RH}$ and $40 \pm 1{ }^{\circ} \mathrm{C}, 75$ $\% \mathrm{RH}$ and analyzed for change in their appearance (white, crystalline and transparent), $\mathrm{pH}$ and drug content. According to results, there was non-significant $(p>0.05)$ change in $\mathrm{pH}$ and drug contents of stored formulations. In addition, no change was observed in appearance of the stored formulations.

\section{In vitro diffusion of flurbiprofen through silicon membrane}

The cumulative amount of flurbiprofen diffused from its gel formulations $\left(G_{1}\right.$ to $\left.G_{13}\right)$ through silicon membrane is presented in Table 6.

Table 5: Viscosity, pH, spreadability, consistency and drug content of the flurbiprofen gels

\begin{tabular}{lccccc}
\hline Formulation & $\begin{array}{c}\text { Viscosity } \\
\left(\mathbf{c p s} \times \mathbf{1 0}^{\mathbf{2}}\right)\end{array}$ & $\mathbf{p H}$ & $\begin{array}{c}\text { Spreadability } \\
(\mathbf{g . c m} / \mathbf{s})\end{array}$ & $\begin{array}{c}\text { Consistency } \\
\mathbf{m m}\end{array}$ & $\begin{array}{c}\text { Drug content } \\
(\mathbf{\%})\end{array}$ \\
\hline $\mathrm{G}_{1}$ & 155 & 5.45 & 5.5 & 7.0 & 98.63 \\
$\mathrm{G}_{2}$ & 162 & 5.65 & 5.0 & 5.0 & 99.81 \\
$\mathrm{G}_{3}$ & 150 & 5.56 & 6.5 & 9.0 & 99.39 \\
$\mathrm{G}_{4}$ & 178 & 5.75 & 5.0 & 3.0 & 99.09 \\
$\mathrm{G}_{5}$ & 166 & 5.60 & 5.5 & 5.5 & 99.86 \\
$\mathrm{G}_{6}$ & 171 & 5.45 & 6.0 & 4.5 & 98.42 \\
$\mathrm{G}_{7}$ & 159 & 5.42 & 6.5 & 7.0 & 97.99 \\
$\mathrm{G}_{8}$ & 168 & 5.52 & 5.0 & 5.5 & 98.98 \\
$\mathrm{G}_{9}$ & 161 & 5.48 & 7.0 & 7.0 & 99.23 \\
$\mathrm{G}_{10}$ & 159 & 5.44 & 5.5 & 6.5 & 99.67 \\
$\mathrm{G}_{11}$ & 162 & 5.47 & 6.5 & 6.0 & 99.30 \\
$\mathrm{G}_{12}$ & 167 & 5.50 & 6.0 & 7.5 & 99.57 \\
$\mathrm{G}_{13}$ & 163 & 5.46 & 5.0 & 6.5 & 99.45 \\
\hline
\end{tabular}


Factor of difference (FoD) of permeation studies of flurbiprofen gel across rat skin vs. silicone membrane

FoD value was 1.726 where flux values determined using silicone membrane at $37 \pm 1$ ${ }^{\circ} \mathrm{C}$ were in the same order of magnitude as that of flux values calculated with rat skin or/and human epidermis for permeation up to $3 \mathrm{~h}$ using optimized G3 showing high flux for silicone membrane (Figure 1). JRS $\left(\mu \mathrm{g} / \mathrm{cm}^{2} / \mathrm{min}\right)$ and $\mathrm{JSM}\left(\mu \mathrm{g} / \mathrm{cm}^{2} / \mathrm{min}\right)$ values were 34.056 and 32.333 , respectively.

Table 6: Cumulative amount $(\mu \mathrm{g} / \mathrm{mL}$, mean $\pm \mathrm{SD})$ of flurbiprofen diffused from its gel formulations $\left(\mathrm{G}_{1}-\mathrm{G}_{13}\right)$ through silicon membrane

\begin{tabular}{|c|c|c|c|c|c|c|c|c|c|}
\hline \multirow{2}{*}{ Formulation } & \multicolumn{9}{|c|}{ Time (min) } \\
\hline & 0 & 15 & 30 & 45 & 60 & 90 & 120 & 150 & 180 \\
\hline $\mathrm{G}_{\mathrm{c}}$ & 0 & $\begin{array}{l}2614.29 \\
\pm 20.31\end{array}$ & $\begin{array}{l}3027.66 \\
\pm 22.30\end{array}$ & $\begin{array}{l}3789.99 \\
\pm 28.41\end{array}$ & $\begin{array}{l}4681.53 \\
\pm 24.56\end{array}$ & $\begin{array}{l}5597.87 \\
\pm 27.68\end{array}$ & $\begin{array}{l}6710.18 \\
\pm 39.02\end{array}$ & $\begin{array}{l}7808.21 \\
\pm 42.59\end{array}$ & $\begin{array}{l}8773.70 \\
\pm 38.32\end{array}$ \\
\hline $\mathrm{G}_{1}$ & 0 & $\begin{aligned} & 2083.45 \\
\pm & 31.30\end{aligned}$ & $\begin{array}{l}2503.21 \\
\pm 34.33\end{array}$ & $\begin{array}{l}3225.53 \\
\pm 12.38\end{array}$ & $\begin{array}{l}3969.56 \\
\pm 38.84\end{array}$ & $\begin{array}{l}4922.23 \\
\pm 39.11\end{array}$ & $\begin{array}{l}5709.04 \\
\pm 31.07\end{array}$ & $\begin{array}{l}6661.09 \\
\pm 24.92\end{array}$ & $\begin{array}{l}7589.46 \\
\pm 28.48\end{array}$ \\
\hline $\mathrm{G}_{2}$ & 0 & $\begin{array}{c}2259.18 \\
\pm 22.37\end{array}$ & $\begin{array}{l}2497.73 \\
\pm 24.83\end{array}$ & $\begin{array}{l}3205.37 \\
\pm 29.20\end{array}$ & $\begin{array}{l}3898.76 \\
\pm 34.81\end{array}$ & $\begin{array}{l}4809.92 \\
\pm 41.04\end{array}$ & $\begin{array}{l}5603.69 \\
\pm 43.94\end{array}$ & $\begin{array}{l}6481.67 \\
\pm 47.38\end{array}$ & $\begin{array}{l}7249.83 \\
\pm 36.67\end{array}$ \\
\hline $\mathrm{G}_{3}$ & 0 & $\begin{array}{c}2174.98 \\
\pm 30.64\end{array}$ & $\begin{array}{l}2454.98 \\
\pm 19.44\end{array}$ & $\begin{array}{l}3084.49 \\
\pm 18.74\end{array}$ & $\begin{array}{l}3799.99 \\
\pm 38.34\end{array}$ & $\begin{array}{l}4682.47 \\
\pm 31.31\end{array}$ & $\begin{array}{l}5699.97 \\
\pm 37.30\end{array}$ & $\begin{array}{l}6704.35 \\
\pm 39.84\end{array}$ & $\begin{array}{l}7698.97 \\
\pm 45.92\end{array}$ \\
\hline $\mathrm{G}_{4}$ & 0 & $\begin{array}{l}2306.77 \\
\pm 24.83\end{array}$ & $\begin{array}{l}2556.31 \\
\pm 31.73\end{array}$ & $\begin{array}{l}3274.32 \\
\pm 28.49\end{array}$ & $\begin{array}{l}4067.03 \\
\pm 31.58\end{array}$ & $\begin{array}{l}4929.66 \\
\pm 37.40\end{array}$ & $\begin{array}{l}5869.27 \\
\pm 28.58\end{array}$ & $\begin{array}{l}6929.48 \\
\pm 19.51\end{array}$ & $\begin{array}{l}7996.25 \\
\pm 34.36\end{array}$ \\
\hline $\mathrm{G}_{5}$ & 0 & $\begin{array}{l}2259.18 \\
\pm 22.58\end{array}$ & $\begin{array}{l}2526.62 \\
\pm 12.09\end{array}$ & $\begin{array}{l}3336.85 \\
\pm 24.16\end{array}$ & $\begin{array}{l}4065.81 \\
\pm 45.19\end{array}$ & $\begin{array}{l}4844.27 \\
\pm 38.36\end{array}$ & $\begin{array}{l}5820.26 \\
\pm 24.08\end{array}$ & $\begin{array}{l}6834.46 \\
\pm 29.04\end{array}$ & $\begin{array}{l}7945.22 \\
\pm 21.57\end{array}$ \\
\hline $\mathrm{G}_{6}$ & 0 & $\begin{array}{c}2134.71 \\
\pm 34.03\end{array}$ & $\begin{array}{l}2556.74 \\
\pm 39.69\end{array}$ & $\begin{array}{l}3287.83 \\
\pm 41.54\end{array}$ & $\begin{array}{l}4040.48 \\
\pm 44.52\end{array}$ & $\begin{array}{l}4998.88 \\
\pm 45.61\end{array}$ & $\begin{array}{l}5796.47 \\
\pm 34.48\end{array}$ & $\begin{array}{l}6757.29 \\
\pm 39.36\end{array}$ & $\begin{array}{l}7694.29 \\
\pm 37.23\end{array}$ \\
\hline $\mathrm{G}_{7}$ & 0 & $\begin{array}{c}2112.74 \\
\pm 45.73\end{array}$ & $\begin{array}{l}2277.96 \\
\pm 36.53\end{array}$ & $\begin{array}{l}2859.89 \\
\pm 39.85\end{array}$ & $\begin{array}{l}3508.67 \\
\pm 31.83\end{array}$ & $\begin{array}{l}4357.33 \\
\pm 37.93\end{array}$ & $\begin{array}{l}5191.78 \\
\pm 42.63\end{array}$ & $\begin{array}{l}6083.11 \\
\pm 40.31\end{array}$ & $\begin{array}{l}7075.54 \\
\pm 41.45\end{array}$ \\
\hline $\mathrm{G}_{8}$ & 0 & $\begin{array}{l}2090.78 \\
\pm 37.03\end{array}$ & $\begin{array}{l}2264.93 \\
\pm 45.61\end{array}$ & $\begin{array}{l}2813.83 \\
\pm 27.93\end{array}$ & $\begin{array}{l}3386.43 \\
\pm 26.79\end{array}$ & $\begin{array}{l}4074.53 \\
\pm 29.86\end{array}$ & $\begin{array}{l}4862.15 \\
\pm 21.56\end{array}$ & $\begin{array}{l}5744.93 \\
\pm 20.36\end{array}$ & $\begin{array}{r}6596.3 \\
\pm 25.57\end{array}$ \\
\hline $\mathrm{G}_{9}$ & 0 & $\begin{array}{c}2438.57 \\
\pm 24.83\end{array}$ & $\begin{array}{l}2663.41 \\
\pm 29.91\end{array}$ & $\begin{array}{l}3410.73 \\
\pm 21.01\end{array}$ & $\begin{array}{l}4139.41 \\
\pm 20.83\end{array}$ & $\begin{array}{l}4878.57 \\
\pm 32.93\end{array}$ & $\begin{array}{l}5859.21 \\
\pm 42.42\end{array}$ & $\begin{array}{r}6828.4 \\
\pm 45.69\end{array}$ & $\begin{array}{l}7738.17 \\
\pm 37.67\end{array}$ \\
\hline $\mathrm{G}_{10}$ & 0 & $\begin{array}{c}2321.42 \\
\pm 39.61\end{array}$ & $\begin{array}{l}2484.13 \\
\pm 37.58\end{array}$ & $\begin{array}{l}3067.05 \\
\pm 34.59\end{array}$ & $\begin{array}{l}3674.14 \\
\pm 32.60\end{array}$ & $\begin{array}{l}4321.61 \\
\pm 30.50\end{array}$ & $\begin{array}{l}5113.22 \\
\pm 45.49\end{array}$ & $\begin{array}{l}6012.64 \\
\pm 41.32\end{array}$ & $\begin{array}{l}6927.46 \\
\pm 25.41\end{array}$ \\
\hline $\mathrm{G}_{11}$ & 0 & $\begin{array}{c}2277.49 \\
\pm 12.15\end{array}$ & $\begin{array}{l}2432.06 \\
\pm 19.91\end{array}$ & $\begin{array}{l}3008.79 \\
\pm 18.12\end{array}$ & $\begin{array}{l}3605.09 \\
\pm 24.09\end{array}$ & $\begin{array}{r}4243.8 \\
\pm 28.07\end{array}$ & $\begin{array}{l}5026.79 \\
\pm 34.03\end{array}$ & $\begin{array}{l}5917.58 \\
\pm 38.82\end{array}$ & $\begin{array}{l}6881.55 \\
\pm 30.38\end{array}$ \\
\hline $\mathrm{G}_{12}$ & 0 & $\begin{array}{c}2310.44 \\
\pm 29.27\end{array}$ & $\begin{array}{l}2464.61 \\
\pm 26.53\end{array}$ & $\begin{array}{l}3046.51 \\
\pm 21.84\end{array}$ & $\begin{array}{l}3647.99 \\
\pm 20.87\end{array}$ & $\begin{array}{l}4291.87 \\
\pm 42.98\end{array}$ & $\begin{array}{l}5080.03 \\
\pm 32.90\end{array}$ & $\begin{array}{l}5975.99 \\
\pm 39.82\end{array}$ & $\begin{array}{l}6945.13 \\
\pm 36.38\end{array}$ \\
\hline $\mathrm{G}_{13}$ & 0 & $\begin{array}{l}2299.46 \\
\pm 45.02\end{array}$ & $\begin{array}{l}2462.42 \\
\pm 33.79\end{array}$ & $\begin{array}{r}3041.9 \\
\pm 35.77\end{array}$ & $\begin{array}{c}3645.54 \\
\pm 15.38\end{array}$ & $\begin{array}{l}4289.57 \\
\pm 17.44\end{array}$ & $\begin{array}{l}5077.73 \\
\pm 42.85\end{array}$ & $\begin{array}{l}5973.69 \\
\pm 35.74\end{array}$ & $\begin{array}{l}6885.07 \\
\pm 38.56\end{array}$ \\
\hline
\end{tabular}

Table 7: Permeation of flurbiprofen gels

\begin{tabular}{|c|c|c|c|c|c|c|c|}
\hline Gels & $t_{\text {lag }}(\min ) \pm S D$ & $\begin{array}{l}\text { Flux }\left(\mu \mathrm{g} / \mathrm{cm}^{2} /\right. \\
\min \pm S D\end{array}$ & $\begin{array}{l}\mathrm{D}\left(\mathrm{Cm}^{2} / \mathrm{min}\right) \times \\
10-{ }^{3} \pm \mathrm{SD}\end{array}$ & $\begin{array}{l}\mathrm{Kp}(\mathrm{Cm} / \mathrm{min}) \times \\
10^{3} \pm \mathrm{SD}\end{array}$ & $\begin{array}{l}K(\mathrm{~cm} / \mathrm{min}) \\
\pm \mathrm{SD}\end{array}$ & ER & $\begin{array}{l}\text { I/R (ug/min) } \\
\pm S D\end{array}$ \\
\hline G1 & $51.327 \pm 0.654$ & $33.31 \pm 0.07$ & $0.66 \pm 8.45 \mathrm{E}-06$ & $33.31 \pm 6.5 \mathrm{E}-05$ & $0.44 \pm 0.01$ & 0.88 & $26.29 \pm 0.05$ \\
\hline G2 & $58.90 \pm 1.91$ & $31.01 \pm 0.34$ & $0.76 \pm 2.46 \mathrm{E}-05$ & $31.01 \pm 0.0003$ & $0.36 \pm 0.02$ & 0.82 & $24.47 \pm 0.27$ \\
\hline G3 & $46.99 \pm 0.19$ & $34.06 \pm 0.02$ & $0.61 \pm 2.48 \mathrm{E}-06$ & $34.06 \pm 1.82 \mathrm{E}-05$ & $0.49 \pm 0.01$ & 0.90 & $26.87 \pm 0.01$ \\
\hline G4 & $49.89 \pm 0.56$ & $34.83 \pm 0.09$ & $0.64 \pm 7.19 \mathrm{E}-06$ & $34.83 \pm 9.18 \mathrm{E}-05$ & $0.48 \pm 0.01$ & 0.92 & $27.48 \pm 0.07$ \\
\hline G5 & $50.47 \pm 0.59$ & $34.41 \pm 0.23$ & $0.65 \pm 7.65 \mathrm{E}-06$ & $34.41 \pm 0.0002$ & $0.47 \pm 0.01$ & 0.91 & $27.15 \pm 0.18$ \\
\hline G6 & $52.21 \pm 0.76$ & $33.65 \pm 0.08$ & $0.67 \pm 9.88 \mathrm{E}-06$ & $33.64 \pm 7.55 \mathrm{E}-05$ & $0.44 \pm 0.01$ & 0.89 & $26.55 \pm 0.06$ \\
\hline G7 & $50.46 \pm 1.15$ & $30.60 \pm 0.16$ & $0.65 \pm 1.48 \mathrm{E}-05$ & $30.60 \pm 0.0002$ & $0.41 \pm 0.01$ & 0.81 & $24.15 \pm 0.13$ \\
\hline G8 & $57.36 \pm 0.37$ & $27.71 \pm 0.09$ & $0.74 \pm 4.74 \mathrm{E}-06$ & $27.71 \pm 4.74 \mathrm{E}-06$ & $0.33 \pm 0.01$ & 0.73 & $21.86 \pm 0.08$ \\
\hline G9 & $59.17 \pm 1.19$ & $32.63 \pm 0.33$ & $0.76 \pm 1.54 \mathrm{E}-05$ & $32.63 \pm 0.00033$ & $0.38 \pm 0.01$ & 0.81 & $25.74 \pm 0.26$ \\
\hline G10 & $64.41 \pm 0.66$ & $28.15 \pm 0.24$ & $0.83 \pm 8.54 \mathrm{E}-06$ & $28.15 \pm 0.0002$ & $0.29 \pm 0.01$ & 0.74 & $22.21 \pm 0.19$ \\
\hline G11 & $62.76 \pm 0.43$ & $28.01 \pm 0.14$ & $0.81 \pm 5.58 \mathrm{E}-06$ & $28.01 \pm 0.00014$ & $0.30 \pm 0.01$ & 0.74 & $22.10 \pm 0.11$ \\
\hline G12 & $63.37 \pm 0.43$ & $28.21 \pm 0.14$ & $0.82 \pm 5.56 \mathrm{E}-06$ & $28.21 \pm 0.0001$ & $0.30 \pm 0.01$ & 0.75 & $22.26 \pm 0.11$ \\
\hline G13 & $64.01 \pm 0.66$ & $28.02 \pm 0.24$ & $0.83 \pm 8.53 \mathrm{E}-06$ & $28.02 \pm 0.0002$ & $0.29 \pm 0.01$ & 0.74 & $22.11 \pm 0.19$ \\
\hline $\mathrm{Gc}$ & $55.86 \pm 0.53$ & $37.83 \pm 0.17$ & $0.72 \pm 6.89 \mathrm{E}-06$ & $37.83 \pm 0.0002$ & $0.46 \pm 0.01$ & 0 & $29.85 \pm 0.13$ \\
\hline
\end{tabular}




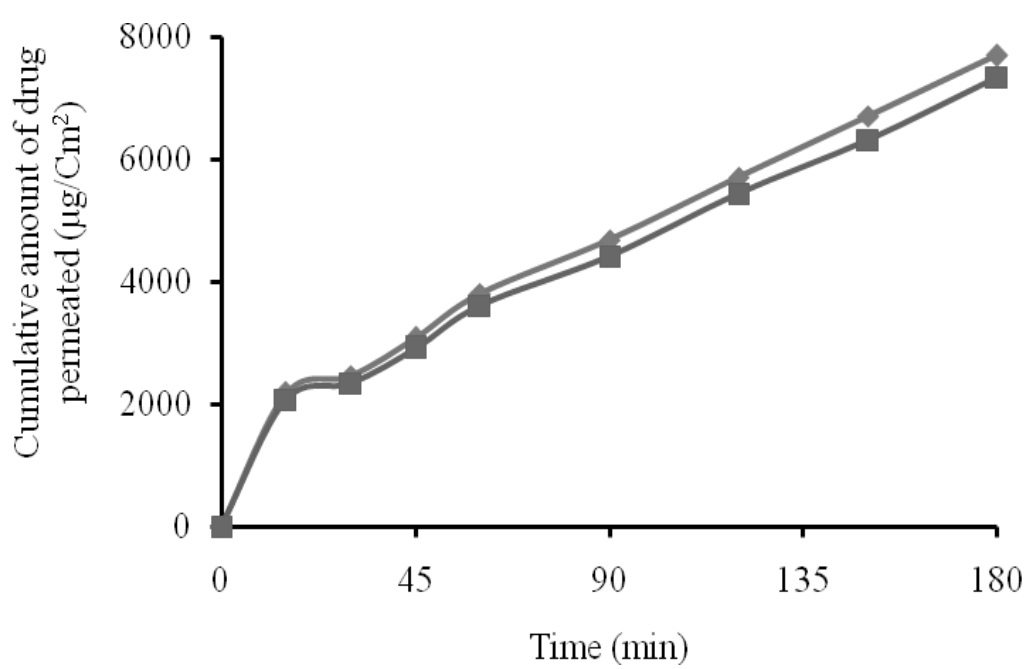

Figure 1: Cumulative amount of drug released from optimized gel $\left(G_{3}\right)$ through silicon membrane and rat skin; $\bullet=$ silicone membrane, $\cdot=$ rat skin

Effect of enhancers on dependent variables

A positive sign of coefficient indicate a synergistic effect whereas a negative sign indicate an antagonistic effect upon response (Figure 2). A large coefficient value means the causal factor has significant influence on response. The three dimensional contour plots present a visual simultaneous effect of causal factors on the response. P-values $(p=0.6709)$ for response $Y_{1}$ represented that the crossproduct contribution $\left(X_{1} X_{2}\right)$ were non-significant $(p>0.05)$, while the quadratic contribution $X_{1}^{2}$ was significant $(p<0.05)$ antagonistic and $X_{2}^{2}$ was non-significant $(p>0.05)$ antagonistic but the linear contribution of $X_{1}$ and $X_{2}$ was nonsignificant $(p>0.05)$ synergistic effect. The relevant polynominal equations are given Eqs 2 8.

$\mathrm{t}_{\text {lag }}=61.11+1.16 \mathrm{X}_{1}+0.038 \mathrm{X}_{2}-1.17 \mathrm{X}_{1} \mathrm{X}_{2}-$ $2.95 \mathrm{X}_{1}^{2}-2.31 \mathrm{X}_{2}^{2}$

Flux $=29.83-0.26 \mathrm{X}_{1}-0.10 \mathrm{X}_{2}+0.77 \mathrm{X}_{1} \mathrm{X}_{2}+$ $1.31 \mathrm{X}_{1}^{2}+0.090 \mathrm{X}_{2}^{2}$.

Diffusion coefficient $=7.888 \mathrm{E}-004+1.503 \mathrm{E}-$ $005 X_{1}+4.898 E-007 X_{2}-1.510 E-005 X_{1} X_{2}-$ $3.810 \mathrm{E}-005 \mathrm{X}_{1}^{2}-2.982 \mathrm{E}-005 \mathrm{X}_{2}^{2}$

Permeability coefficient $(\mathrm{KP})=0.030-2.552 \mathrm{E}$ $004 X_{1}-1.024 E-004 X_{2}+7.682 E-004 X_{1} X_{2}+$ $1.308 \mathrm{E}-003 \mathrm{X}_{1}^{2}+9.030 \mathrm{E}-005 \mathrm{X}_{2}^{2}$

Partition co-efficient $(\mathrm{K})=0.34-0.013 \mathrm{X}_{1}-$ $3.155 \mathrm{E}-005 \mathrm{X}_{2}+0.016 \mathrm{X}_{1} \mathrm{X}_{2}+0.035 \mathrm{X}_{1}^{2}+$ $0.015 \mathrm{X}_{2}^{2}$
Enhancement ratio $(E R)=1.00-0.020 X_{1}-$ 7.676E - 003X $-2.875 \mathrm{E}-004 \mathrm{X}_{1} \mathrm{X}_{2}+7.175 \mathrm{E}-$ $003 \mathrm{X}_{1}^{2}+6.784 \mathrm{E}-003 \mathrm{X}_{2}^{2}$

Input rate $(\mathrm{IR})=23.54-0.20 \mathrm{X}_{1}-0.081 \mathrm{X}_{2}$ $+0.61 X_{1} X_{2}+1.03 X_{1}^{2}+0.071 X_{2}^{2}$

The equations indicate that $P G$ and PEG have a strong and positive effect on permeation of flurbiprofen. The combined effect of both factors has negative and antagonistic effect on permeation as they antagonize each other to facilitate permeation. From $T_{\text {lag }}$ equation, the two terms containing $\mathrm{X}_{1}\left(1.16 \mathrm{X}_{1}-2.95 \mathrm{X}_{1}^{2}\right)$ showed that $t_{\text {lag }}$ decreased with increasing concentration of PG.

\section{DISCUSSION}

The stratum corneum (SC) of mammalian skin acts as selectively permeable membrane. It allows the diffusion of lipid molecules through spaces present among keratinocytes [10]. The lipid intercellular materials are dissolvable using suitable chemicals substances such as PG and PEG which are documented as excellent permeation enhancers [9]. These enhancers are found to promote drug permeation in concentration-dependent mode, i.e. permeation was influenced by the concentration of $P G$ and PEG-1000. It means that the rate of permeation through rat skin occurred as per Fickian diffusion law. This increase in drug permeation with increased enhancer amounts might be due to some effect of enhancers on the skin which was described above. Moreover, drug permeation enhancement effect of PG is further improved by adding increasing concentration of PEG. It shows 

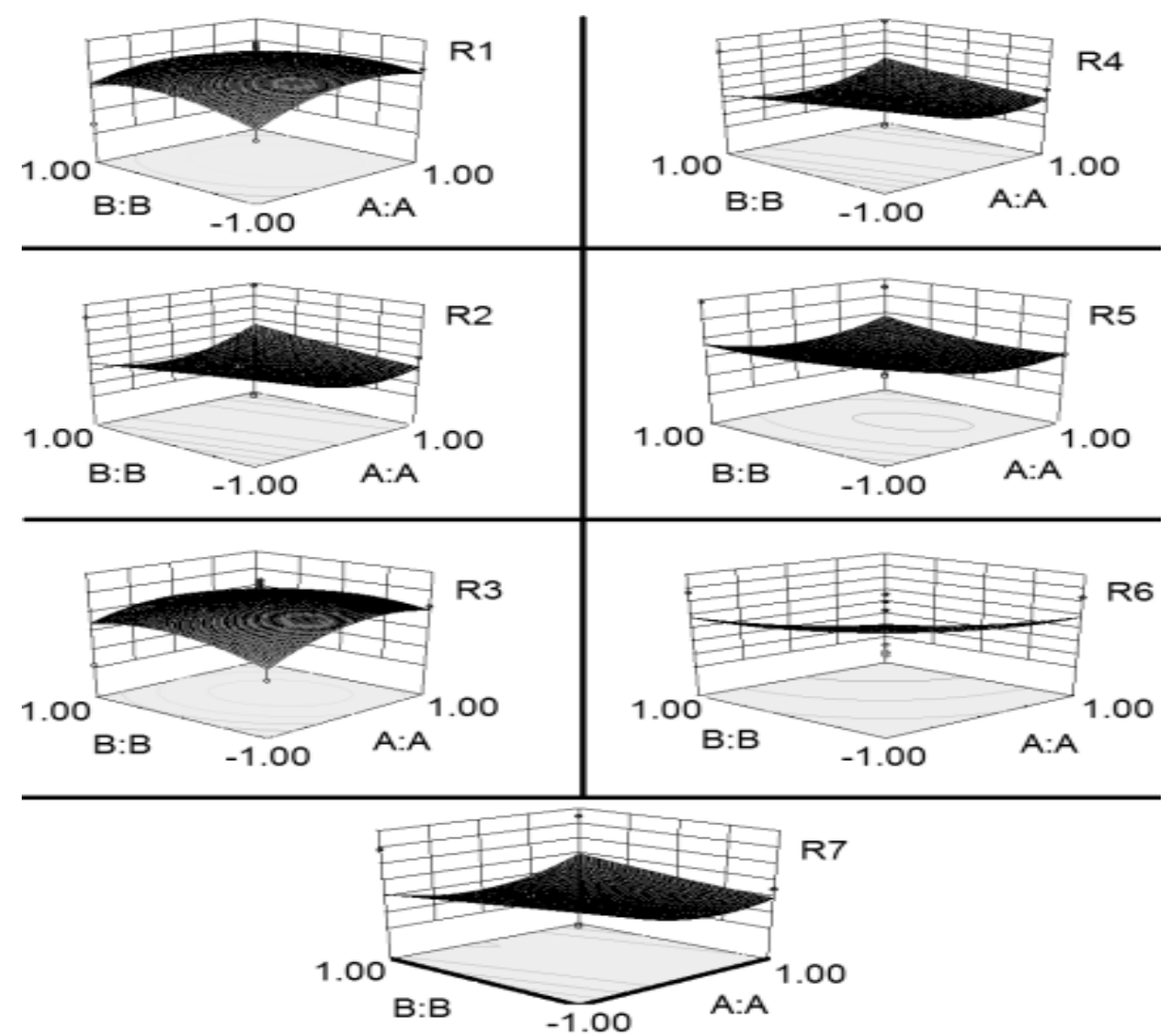

Figure 2: Response surface plot showing the influence of $P G$ and PEG on various dependent variables

synergism in their permeation enhancement when both enhancers are used simultaneously. These results are in accordance with our previously published findings $[9,11]$.

\section{CONCLUSION}

PG and PEG are effective enhancers of flurbiprofen penetration from the various formulations. It seems that experimental outcomes that enhance the effect of $P G$ and PEG are not only due to the changing solubility of these formulations in the solvent system, but also due to the transport rate of the permeant (flurbiprofen) mostly by diffusion.

\section{REFERENCES}

1. Aamir MF, Ahmad M, Murtaza G, Khan SA. In Vitro/In Vivo Assessment of Flurbiprofen-Matrix type Transdermal Delivery System. Latin Am J Pharm 2011; 30(2): 318-324.

2. Sharif A, Rabbani ME, Akhtar MF, Akhtar B, Saleem A, Farzana K, Usman A, Murtaza G. Design and evaluation of modified release bilayer tablets of flurbiprofen. Adv Clin Exp Med 2011; 20(3): 343-349.

3. Khan SA, Ahmad M, Murtaza G, Aamir MN, Madni MA, Kousar R, Asghar MW. Formulation of two-drug controlled release non-biodegradable microparticles for potential treatment of muscles pain and spasm and their simultaneous spectrophotometeric estimation. Acta Pol. Pharm. Drug Res. 2010; 67(3): 299-306.

4. Shahzad, M. K, Ubaid, M, Raza, M, Murtaza G. The formulation of flurbiprofen loaded microspheres using hydroxypropylmethylcellulose and ethylcellulose. Adv. Clin. Exp. Med. 2013; 22(2): 177-183.

5. Ahmad M, Ahmad R, Murtaza G. Comparative Bioavailability and Pharmacokinetics of Flurbiprofen $200 \mathrm{mg}$ SR Pellets from India and France. Adv Clin Exp Med 2011; 20(5): 599-604.

6. Khan SA, Ahmad M, Murtaza G, Muhammad NA, Nisar UR, Rozina K, Fatima R, Mohammad A. Formulation of nimesulide floating microparticles using low viscosity hydroxypropyl mehylcellulose. Trop. J. Pharm. Res. 2010; 9(2): 293-299.

7. Murtaza G, Ahmad M, Shehnaz G. Microencapsulation of diclofenac sodium by non-solvent addition technique: Use of toluene and petroleum benzin as solvent and non-solvent respectively. Trop. J. Pharm. Res. 2010; 9(1): 187-195.

8. Murtaza G. Development of glutaraldehyde cross-linked metronidazole loaded chitosan microcapsules: analysis of dissolution data using $D D$-Solver. Latin Am. J. Pharm. 2011; 30(2): 301-308.

9. Shah SNH, Tahir MA, Safdar A, Riaz R, Shahzad Y, Rabbani M, Karim S, Murtaza G. Effect of Permeation Enhancers on the Release Behavior and Permeation

Trop J Pharm Res, February 2015; 14(2): 202 
Kinetics of Novel Tramadol Lotions. Trop J Pharm Res 2013; 13(1): 27-32.

10. Shah SNH, Rabbani ME, Shahzad Y, Badshah A, Meidan YM, Murtaza G. Developing an efficacious diclofenac diethylamine transdermal formulation. J. Food Drug Anal. 2012; 20(1): 464-470.

11. Ansari MT, Haneef M, Murtaza G. Solid Dispersions of Artemisinin in Polyvinyl Pyrrolidone and Polyethylene Glycol. Adv. Clin. Exp. Med. 2010; 19(1): 745-754. 